\title{
An Investigation on Mobile Banking and Co-creation Services Adoption Intention in South Africa
}

\author{
https://doi.org/10.3991/ijim.v14i11.13755 \\ Marike Venter de Villiers \\ University of the Witwatersrand, Johannesburg, South Africa \\ Tinashe Chuchu $(\bowtie)$ \\ University of Pretoria, Pretoria, South Africa \\ tinashe.chuchu@up.ac.za \\ Gugu Valerie Chavarika \\ University of the Witwatersrand, Johannesburg, South Africa
}

\begin{abstract}
Co-creation of value between the consumer and services providers is an idea that has been receiving much attention. The purpose of this study was to investigate the influence of consumer motivation on attitudes and adoption intention of co-creational banking activities. By means of a quantitative method, 339 surveys were collected. The research instrument was compiled from existing scales that were adopted for the purpose of this study. The proposed conceptual model and hypotheses were tested using Structural Equation Modeling (SEM), while scale reliability and validity was confirmed using SPSS 23. Further, AMOS 23 was used to test the model fit. The findings indicated that all seven proposed hypotheses are significant. Therefore, indicating that consumer motives have a positive influence on a consumer's attitudes toward participating in co-creation activities, which in turn has an impact on relative advantage, complexity and compatibility. Lastly, the results indicate that relationships exist between relative advantage, complexity and compatibility, respectively and adoption intention. This study adds to contextual knowledge of co-creational adoption within digital banking, and provides managers with significant insight into the potential success of digital customization and how banks can benefit from digital co-creation.
\end{abstract}

Keywords-Co-creation, digital, banking, adoption, South Africa.

\section{Introduction}

In recent years the adoption of advanced technologies that include mobile banking services has grown exponentially among consumers and service providers in the financial sector [1], [2], [3]. South African financial institutions are described as well developed, proactively regulated and on par with global [4]. Although 'concentrated' with four major players, the banking sector remains competitive as each bank continues to broaden its products and services to attract new customers and satisfy its existing client base [5]. The competitive and dynamic nature of the banking sector is a response to 
forces of change in the context of technology, customer behavior and regulation [6]. Banks have evolved from paper-based banking services provider modern paper-less technologies such as mobile banking [7]. In particular, changes in technology and customer behavior have led to the global emergence of digital banking. The emphasis of digital banking is on using technology to design meaningful experiences for the consumer. Furthermore, digital banking focuses on electronic data and online platforms as the core of a bank's operations, instead of being organized around money in branches [8]. Since consumer behavior is changing - consumers want the ability to manage their money anytime and anywhere through personalized digital offers [9] central to the successful implementation of digital banking offerings is the consumer.

The value co-creation process occurs when the supplier provides greater value propositions, with customers deciding value when a product or service is consumed [10]. Previous research on co-creation suggests the outcomes of conducting co-creation activities with consumers are abundant and are mutually beneficial for the firm and its consumers [11], [12]. Research shows that some of the benefits of co-creation include value creation for the firm and consumer [13], [12], [14] increased consumer loyalty and commitment [13], [15] strong competitive advantage [15] and a re-ignition of the firm's growth and innovation capabilities [16], [12]. Thus, the focus of this study is on consumer's motivation on attitudes and adoption intention of co-creational banking activities. In particular, the study aims to fill a gap by determining whether consumer motives influence their attitudes toward participation in co-creation activities in the digital banking industry in South Africa. Additionally, the study presents the impact of relative advantage, complexity and compatibility on adoption intention of co-creational activities.

\section{$2 \quad$ Literature Review}

\subsection{Mobile banking}

Traditional banks expressed their need to engage in mobile banking due to its capability to facilitate services at anyplace regardless of time [17], [18]. Traditionally, banks were organised around the physical distribution of money amongst a network of branches [19]. However, with the emergence of technology, present banks are facing various challenges such as changing consumer patterns and competition, which has resulted in a new kind of banking, mobile banking. Banks such as Egg in Britain [20] and Fidor in Germany [8] exist only on digital platforms. Consequently, a number of banks are extending their services to online platforms, while others are shutting down branches and shifting towards a more digital business model [8]. This is largely done in response to changing consumer behavior patterns as individuals are looking for an experience which is secure and seamless [21]. The results of this transformation in the industry include an enhanced consumer experience, convenience, and consumer empowerment [6], [20], [22]. In addition, banks that pursue a digital transformation can expect improvements in earnings, taxes, depreciation and amortisation of more than $40 \%$ [23]. 


\subsection{Co-creation services}

Co-creation is based on the premise that firms and consumers must collaborate to create value [14]. This term was initially coined by [14], who emphasized the relevance of co-creation amid the continuously spreading prevalence of the Internet, the challenging competitive environment and consumers who are becoming motivated, empowered and connected. The future of competition and gaining a sustained competitive advantage is therefore based on an individual-centered co-creation system between the corporation and its consumers [14]. The importance of co-creation has been emphasized in a number of related studies. For instance, [12] suggest that consumers are demanding greater levels of personalization and are placing brands under pressure to generate and develop value with them, rather than for them. Similarly, [24] shares these sentiments and emphasize that co-creation is the strength of the collective intelligence of consumers. Furthermore, the outcomes of conducting co-creation activities with consumers are abundant and are mutually beneficial for the firm and its consumers [11], [12], [14]. According to [25], high levels of consumer involvement in co-creation activities positively influence consumer's attitudes towards a brand, which ultimately leads to high purchase intention. It is therefore imperative for businesses to engage in co-creation with consumers, as they will reap the financial rewards from such engagements.

\section{$3 \quad$ Theoretical Grounding}

This study is grounded in two theories, namely [26] Self-Determination Theory (SDT) and [27] Diffusion of Innovation Theory.

\subsection{Self-determination theory}

Since [26] first proposed the Self-Determination Theory (SDT), it has been popularly used to examine motivational factors that affect an individual's behavior in various contexts. SDT is focused on the processes through which an individual acquires motivation to initiate new behaviors and maintain them over time [28]. Furthermore, the theory is broken down into three areas: needs, level of self-determination and type of motivation. In terms of the present study, the type of motivation is of interest. SDT distinguishes between different types of motivation (intrinsic and extrinsic) based on the reasons that give rise to an action, which regulate an individual's behavior [29].

\subsection{Diffusion of innovation theory}

The innovation diffusion model developed by [27] is the most popular, in determining how innovations are adopted over time, amongst researchers [30], [31] from various fields such as political science [31], public health [32], and marketing [33]. According to [34], the diffusion of an innovation is the process in which an innovation is communicated through certain channels over time among members of a social system. This 
definition suggests that four key elements of the diffusion of innovation exist: (1) innovation, (2) communication channels, (3) time and (4) social system. In terms of the present study, the innovation element is of importance as the theory proposes five attributes (or perceived characteristics) of an innovation, which help consumers decide whether or not to adopt an innovation and the rate at which the innovation is likely to be adopted.

\subsection{Hypothesis development}

Motives and attitude (H1): Motivation is the driving force behind all behavior and is likely to influence consumers' attitude towards participating in a certain behavior [35]. The relationship between motives and attitudes has been explored in several studies. For instance, [36] conducted a study that investigated the effect of both intrinsic and extrinsic factors in determining the consumer attitudes towards products. The results indicated that intrinsic motives had a positive influence on consumer attitudes toward products. In a study conducted within the context of co-creation, it was found that individuals who participated in co-creation activities are more likely to experience a higher degree of fun and involvement, thus increasing the level of participation with the brand [37]. According to [38], motivations directly associated with attitudes. This assertion was supported by [39] who also suggested that motivation was an antecedent of attitude. Thus, the present study proposes the following:

- H1: Motives have a positive influence on attitudes toward participating in co-creation activities.

Attitude and relative advantage (H2): Previous studies have explored the relationship between consumer attitudes and their future behavior intentions [40], [41]. More specifically, in a study conducted by [42] they examined the determinant structure of a consumer's attitude system on the adoption of internet banking among Malaysian customers. The results showed that attitudinal factors play a significant role in the adoption of Internet banking. Thus, if a consumer has a favorable attitude toward participating in co-creation activities, he or she is likely to have intentions to adopt the innovation. Based on the aforementioned studies, it is evident that attitudes toward participation in co-creation activities impact a consumer's perceptions of relative advantage of a cocreated innovation. Thus, the present study proposes the following:

- H2: There is a positive relationship between attitudes toward participating in cocreation activities and relative advantage.

Attitude and complexity (H3): [43] suggested that complexity influences attitudes. In line with the hypothesis proposed by [43], [44] found that adoption rate of technology is higher if it is easy to use. [45] supported this finding that complexity adversely affects Internet usage and thus, complexity in mobile applications would negatively impede the development of a positive attitude towards applications. Similarly, [46] found that if users' view mobile banking services as easy to use, they form positive attitudes towards them [47]. 
- H3: There is a negative relationship between attitudes toward participating in cocreation activities and complexity.

Attitude and compatibility (H4): In the majority of studies on consumer attitudes and compatibility, it was found that the more favorable consumers' attitudes towards an innovation, the more likely that they will perceive it as being compatible with their current knowledge base. Compatibility refers to the degree to which an innovation is perceived to be compatible with individuals existing values, beliefs, habits and previous experiences [48]. Attitude is directly influenced by compatibility [49]. However, compatibility affects attitude toward behaviour with the aid of ease of use and competitive advance offered by the technology [49]. The notion that perceived compatibility directly influenced consumer attitudes toward adopting a technology was also supported by [50] who examined business to customer (B2C) attitudes in the adoption of technological innovations. The present study therefore proposes the following hypothesis:

- H4: There is a positive relationship between attitudes towards participating in cocreation activities and compatibility.

Relative advantage and adoption intention (H5): Various researchers have studied the relationship between relative advantage and adoption intention. For instance, [42] suggest that relative advantage is an important factor in determining the adoption of new innovations as the construct is positively related to its rate of adoption. Similarly, [51], and [52] confirmed these findings and concluded that relative advantage is the best predictor of adoption intention. Specifically, [46] examined the effect of innovation attributes such as relative advantage on consumer attitudes and behavioral intentions of consumers to adopt mobile banking. The results of the study found that relative advantage does indeed have a positive impact on intentions to adopt or continue to use mobile banking. Thus, the present study proposes the following:

- H5: There is a positive relationship between relative advantage and adoption intention.

Complexity and adoption intention (H6): Several studies have explored the relationship between complexity and adoption intention. For example, [45] found that complexity negatively influences the adoption of an innovation. For this reason, complexity is described as the opposite of ease of use, which has been found to directly impact the adoption of the internet-based technologies [42]. Thus, it is suggested that the less complex something is to understand and use, the more likely a consumer will adopt it [52]. [53] considered the inherent complexity of new technology and investigated the impact of complexity on a consumer's intention to use a new technology. The results indicated that both complexity and perceived difficulty had a negative impact on the consumer's behavioral intention. Thus, the present study proposes the following:

- H6: There is a negative relationship between complexity and adoption intention. 
Compatibility and adoption intention (H7): A number of studies have investigated the relationship between compatibility and adoption intention and the majority of results point towards evidence that an innovation is more likely to be adopted when it is compatible with an individual's current value system. [42] suggest that compatibility may be the most relevant attribute influencing the potential adoption of an innovation. Intention to adopt is the influenced by attitudes [54]. The findings of [55] confirmed that the compatibility of an innovation with a consumer's value system has a significant positive and direct effect on the consumer's intentions. Thus, it can be said that a lack of compatibility of an innovation with a consumer's lifestyle, needs and experiences may negatively affect his/her use of the innovation [31]. [56] investigated the intentions of taking up e-learning were examined and the findings revealed that compatibitly had a significant influence on the e-learning adoption intention when compared to other relavant innovation attributes. Accordingly, it is evident that compatibility has a relationship with adoption intentions. Thus, the present study proposes the following:

- H7: There is a positive relationship between compatibility and adoption intention.

Figure 1 presents the proposed conceptual model for the study. Firstly, consumer motives represent the predictor variable with adoption intention as the outcome variable. Within the proposed model, there are four inter-construct variables, namely: attitude toward the act, relative advantage, complexity and compatibility. It is therefore proposed that consumer motives have a positive influence on attitudes toward participating in co-creation activities, which in turn has a positive impact on relative advantage and compatibility and a negative impact on complexity. It follows that relative advantage and compatibility have a positive relationship with adoption intention, respectively, while complexity has a negative relationship with adoption intention.

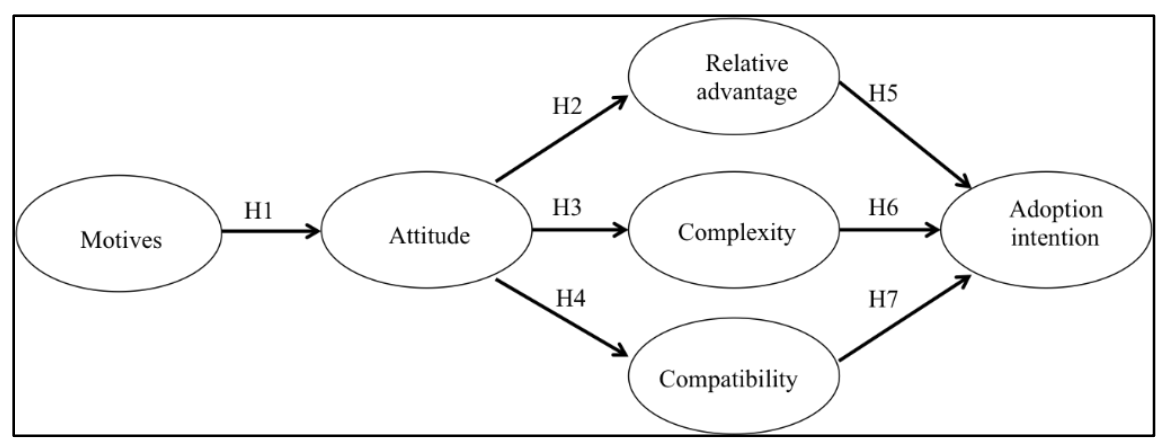

Source: Venter de Villiers, Chuchu \& Chavarika (2020)

Fig. 1. Proposed Conceptual Model

\section{$4 \quad$ Research Methodology}

The present study assumed a positivist research approach and examined the relationships between the dependent and independent variables. By means of a quantitative 
method, the research instrument was compiled from existing scales that were adopted for the purpose of the present study. The proposed conceptual model and hypotheses were tested using Structural Equation Modeling (SEM), while scale reliability and validity was confirmed using SPSS 23 . Further, AMOS 23 was used to test the model fit.

\subsection{Sample and data collection}

The population of interest for the purpose of this study was individuals between the ages of 18 and 64 years of age, all who have active bank accounts within South Africa. A convenient sample of 400 respondents were selected, with a response rate of $85 \%$ and therefore 339 completed surveys were collected. The data collection was conducted amongst two hundred and fifty respondents that belong to the Generational Y cohort. By means of random sampling, respondents were selected on university campuses as well as the researcher's Facebook friends that fall within this age group. [57] recommended a minimum sample size of at least 100, whereas researchers with more recent work argue that 100 is a poor sample size and suggest that 200 is fair and 300 is good [58]. [59] suggest that when using Structural Equation Modeling, the minimum size of a sample should be 200. Thus in light of all the above recommendations in past literature, the study obtained 339 completed surveys from an initial sample of 400 . The sample included both male and female students from different social and financial backgrounds.

\subsection{Measurement instrument and questionnaire design}

The measurement instrument comprised a questionnaire of 30 statements. The research scales were adopted from previous measurement scales to suit the context of the present study. The first variable, motives, was measured using an adaptation of [60] and [61] motivational scales. To measure attitude, and adaption of [62] scale was used. Relative advantage, complexity and compatibility were measured using [63] scale items, while adoption intention was measured using an adaptation of [64] and [65] scale items. All scales were measured using a 7-point Likert scale.

\subsection{Ethical considerations}

In relation to research ethics, the researchers received an ethics clearance certificate that granted permission to collect data from human subjects. This was because the data concerned confidential banking habits of consumers. All participants were informed that the research was anonymous and confidential. Last, the participation in the research was voluntary and respondents were allowed to withdraw at any stage.

\section{$5 \quad$ Findings / Results}

This section provides an overview of the respondent profile, the model fit and hypotheses results. 
Table 1. Sample Profile

\begin{tabular}{|l|c|c|}
\hline \multicolumn{3}{|c|}{ Gender } \\
\hline Male & Frequency & Percent \\
\hline Female & 201 & 59.3 \\
\hline Total & 138 & 40.7 \\
\hline \multicolumn{3}{|c|}{ Age } \\
\hline & 339 & Percent \\
\hline $18-24$ & 203 & 60 \\
\hline $25-34$ & 54 & 16.0 \\
\hline $35-44$ & 34 & 10.0 \\
\hline $45-54$ & 48 & 14.0 \\
\hline Total & 339 & 100.0 \\
\hline & Level of Study & Percent \\
\hline & Frequency & 11.0 \\
\hline High school & 38 & 4.0 \\
\hline Diploma & 14 & 36.0 \\
\hline Undergraduate & 122 & 49.0 \\
\hline Postgraduate & 166 & 100.0 \\
\hline Total & 339 & \\
\hline
\end{tabular}

Source: Compiled from SPSS output (2018)

\subsection{Assessing measurement model fit}

This section presents the analysis of model fit by means of assessing various indices in order to determine the degree of acceptable or good model fit (Table 2). The following indices are examined: Chi-square (CMIN), the normed fit index (NFI), relative fit index (RFI), incremental fit index (IFI), Tucker-Lewis Index (TLI), goodness of fit index (GFI), and the Root Mean Square Error of Approximation (RMSEA). Table 2 presents the results of the model fit indices.

Table 2. Model Fit

\begin{tabular}{|c|c|c|c|c|c|c|}
\hline CMIN & NFI & RFI & IFI & TLI & CFI & RMSEA \\
\hline 2.39 & 0.96 & 0.92 & 0.98 & 0.95 & 0.98 & 0.06 \\
\hline
\end{tabular}

Source: Compiled from AMOS output (2018)

It is evident from Table 2 that all the model fit indices reach the required thresholds: the RMSEA indicated a value of 0.06 , which is below 0.08 as recommended by [66]. Furthermore, the CMIN, NFI, RFI, IFI, TLI and CFI all meet the recommended threshold of 0.9 [67]. 
Table 3. Hypothesis Results

\begin{tabular}{|l|c|c|l|}
\hline \multicolumn{1}{|c|}{ Hypothesis } & & P Value & \multicolumn{1}{c|}{ Outcome } \\
\hline Motives $\rightarrow$ Attitude $(\mathrm{H} 1)$ & 0.77 & $* * *$ & Supported and Significant \\
\hline Attitude $\rightarrow$ Perceived Relative advantage (H2) & 0.81 & $* * *$ & Supported and Significant \\
\hline Attitude $\rightarrow$ Perceived Complexity (H3) & -0.32 & $* * *$ & Supported and Significant \\
\hline Attitude $\rightarrow$ Perceived Compatibility (H4) & 0.54 & $* * *$ & Supported and Significant \\
\hline Perceived Relative advantage $\rightarrow$ Adoption intention (H5) & 0.27 & $* * *$ & Supported and Significant \\
\hline Perceived Complexity $\rightarrow$ Adoption intention (H6) & -0.17 & 0.002 & Supported and Significant \\
\hline Perceived Compatibility $\rightarrow$ Adoption intention (H7) & 0.34 & 0.001 & Supported and Significant \\
\hline
\end{tabular}

Source: Compiled from AMOS output (2018)

\subsection{Hypotheses results and path coefficients}

An examination of the results recorded in Table 3, found that all of the hypotheses were significant, with two of the seven hypotheses indicating an inverse relationship (H3 and H6). On closer inspection, the strongest relationship was found to be hypothesis two, which tested the relationship between attitude and perceived relative advantage (0.77). This implies that if consumers have a positive attitude towards co-creational innovation, they will perceive a greater level of relative advantage towards engaging in co-creational activities. Another strong relationship was found between motives and attitude (H1). In other words, if they have a strong motivation for engaging in a cocreational activity, they are more likely to have a positive attitude towards co-creation. The weakest relationship exists between perceived relative advantage and adoption intention (H6), with a path coefficient of 0.27. From this result it is evident that although consumers may perceive the co-creational activity as providing them with a relative advantage, they may be hesitant towards adopting the innovation. The two inverse relationships were found to be between attitude and perceived complexity (H3), and perceived complexity and adoption intention (H6) respectively. This indicates that the more positive their attitude is towards co-creation, the less complex they would perceive the activity to be.

\section{Discussion and Conclusions}

The findings of the present study provide consistent results in light of previous literature. For instance, the first hypotheses indicated that consumer's motives have a positive influence on attitude towards participating in co-creation activities. Previous literature from a number of authors have found that intrinsic and extrinsic motives influence consumers' attitude towards adopting an innovation, a product or participation in a certain behavioural activity [36], [37], [68], [69]. The second hypothesis indicated that consumers' attitudes have a positive influence on participating in co-creation activities if they perceive to gain a relative advantage. Previous studies have explored the relationship between these constructs and found a positive relationship [40], [41]. In other words, if consumers perceive to gain an advantage from purchasing a product, they are more likely to have a favorable attitude towards toe innovation. Thirdly, a negative 
relationship was found between consumers' attitudes towards participating in co-creation activities and their perceived complexity of engaging in such activities. This finding is consistent with a number of studies [47], [45], [44], [46], which provided evidence that consumers' are more likely to have a favourable attitude towards adopting an innovation if they perceive it as being easy to use. Fourthly, attitude was found to have a positive relationship with consumers' perceived compatibility of engaging in cocreation activities. In the majority of studies on attitude and compatibility, it has been found that consumers are more likely to have a favorable attitude towards an innovation if they perceive it to be consistent with their current knowledge base, beliefs and value systems [72], [49], [50]. The fifth hypothesis provided evidence of a positive relationship between perceived relative advantage of participating in co-creation activities and adoption intention. In previous studies, [42] found that relative advantage is an important determinant of adoption intention of new innovations. Similarly, a number of studies provided consistent results [51], [52]; [46].

The results from hypothesis six indicated a negative relationship between consumers' perception of the complexity of participating in the co-creation and their adoption intention. A number of studies have explored this relationship [45], [52], [42], [53] These studies found that the less complex an innovation is to understand, the more likely that consumers will consider adopting it. Lastly, a positive relationship was found between consumers' perceived compatibility with participating in the co-creation activity and their intention to adopt such. Previous studies [56], [42], [31], [55] have confirmed that the more compatible an innovation is with an individual's values, current knowledge base and value system, the more likely that they will adopt the innovation.

\subsection{Managerial implications}

Based on the results of the present study, a number of practical managerial implications for banks exist. The study acts as a guide for banks when developing marketing strategies relating to innovation and co-creation in digital banking. For instance, banks could initiate activities that speak to their consumers' sense of fun, interest and excitement. In other words, if consumers are motivated by the act of enjoying the co-creational activity, they are likely to have a favorable attitude towards using it. Marketers should therefore focus on the 'fun' and 'enjoyment' aspect in their branding and marketing message. For example, invite consumers to be part of the brainstorming session when creating banking products or designing the smartphone application/website. Further, banks should communicate and emphasize the advantage that consumer will get from using the innovation. For example, have a campaign that focuses on the time that they may save from using the innovation or the ability of the customer to 'customize' their banking experience. Banks could also explore benefits such as user-friendliness of the innovation when consumers are involved in the co-creational process of using the innovation. The advantage that the consumer may get from participating will benefit them, as they might have been part of the development process and such, the product offerings are customized to suit their individual needs. Additionally, attitudes towards participating in co-creation activities have a positive impact on a consumer's perception of the compatibility of the innovation. 


\subsection{Limitations and direction for future research}

Although this study has made great contributions to literature and practitioners, some limitations exist. Firstly, this study was conducted in the context of digital banking. This may limit the results to the banking industry only and may influence the generalizability of the results. Additionally, the study was conducted in an emerging economy, South Africa, and the results may not be generalizable to emerged economies. Lastly, the study was conducted using various channels including online and in person. The online channel may have posed a limitation, as respondents may have not been forthcoming when discussing banking habits online. Additionally, online surveys are sometimes rushed through or not fully understood as a researcher is present to monitor and assist respondents if need be. Having highlighted the importance of this study, future research could compliment this study. For example, researchers can determine the perceptions of co-creation within the organization (employees and management). For cocreation to be successful management in the organization must be willing to lead the firm into a new marketing logic (Service-Dominant Logic) and employees must buy into the transformed role of the firm which focuses on on-going mutually beneficial relationships [15]. Additionally, researchers can replicate the study, but instead apply it to different context instead of the banking industry. [70] suggest that co-creation strategies can exist in various contexts including in social innovation where citizens are involved to develop solutions in areas of healthcare and education [71]. Conceptually, potential hypothesis could be tested that were left-out of this study. For instance, further research could involve the analysis of the relationship between relative advantage and complexity. In addition it could also be necessary to test the relationship between complexity and compatibility. This is because of the perception of risk that banking customers in South Africa place on banking services [73]. This would possibly reveal how important the mediators between attitude and adoption and intention are? The mediators, relative advantage, complexity and compatibility could be removed in order to assess the direct impact that attitude has on adoption intention. Lastly, researchers can consider a study that looks at the tangible results of co-creation, rather than consumers' intentions to adopt.

\section{$7 \quad$ References}

[1] Gharaibeh, M. K., Arshad, M. R., \& Gharaibeh, N. K. (2018). Using the UTAUT2 Model to Determine Factors Affecting Adoption of Mobile Banking Services: A Qualitative Approach. International Journal of Interactive Mobile Technologies, 12(4), 123-134. https:// doi.org/10.3991/ijim.v12i4.8525

[2] Jun, M. \& S. Palacios, (2016). Examining the key dimensions of mobile banking service quality: an exploratory study. International Journal of Bank Marketing, 2016. 34(3): p. 307326. https://doi.org/10.1108/ijbm-01-2015-0015

[3] Oliveira, T., Faria, M., Thomas, M. A., \& Popovič, A. (2014). Extending the understanding of mobile banking adoption: When UTAUT meets TTF and ITM. International journal of information management, 34(5), 689-703. https://doi.org/10.1016/j.ijinfomgt.2014.06. $\underline{004}$ 
[4] The Banking Association. (2015). Association and Industry Overview. Retrieved September 4, 2015, from Banking: http://www.banking.org.za/about-us/association-overview

[5] Mlambo, K., \& Ncube, M. (2011). Competition and Efficiency in the Banking Sector in South Africa, African Development Review, 23(1), 4-15. https://doi.org/10.1111/j.1467$\underline{8268.2010 .00268 . \mathrm{x}}$

[6] Grosskopf, J. and Beyers, S. (2015). Resilient Through Challenging Times: Major Banks Analysis South Africa. Johannesburg: PWC.

[7] Aldiabat, K., Al-Gasaymeh, A., \& Rashid, A. K. (2019). The Effect of Mobile Banking Application on Customer Interaction in the Jordanian Banking Industry. International Journal of Interactive Mobile Technologies. 13(2), 37-49. https://doi.org/10.3991/ijim.v13i02. $\underline{9262}$

[8] Groenfeldt, T. (2014). Digital Banking: An Expert Guide on How to Get There. Retrieved November 27, 2015, from Forbes: http://www.forbes.com/sites/tomgroenfeldt/2014/12/28/digital-banking-an-expert-guide-on-how-to-get-there/2/

[9] Sengupta, J., Lam, K. and Desmet, D. (2014). Asia Financial Institutions "Digital Banking in Asia" Winning approaches in a new generation of financial services. McKinsey \& Company.

[10] Payne, A. F., Storbacka, K., \& Frow, P. (2008). Managing the co-creation of value. Journal of the academy of marketing science, 36(1), 83-96. https://doi.org/10.1007/s11747-007$\underline{0070-0}$

[11] Roberts D, Hughes M \& Kertbo K (2014) Exploring consumers' motivations to engage in innovation through co-creation activities. European Journal of Marketing 48(1/2): 147-169. https://doi.org/10.1108/ejm-12-2010-0637

[12] Roser, T., Samson, A., Humphreys, P. \& Cruz-Valdivieso, E. (2009). New Pathways to Value: Co-creating Products by Collaborating with Customers. LSE Enterprise, London, UK.

[13] Verleye, K. (2015). The Co-creation Experience from the Customer Perspective: Its Measurement and Determinants. Journal of Service Management, 26, pp. 321-342. https://doi. org/10.1108/josm-09-2014-0254

[14] Prahalad, C. K. \& Ramaswamy, V. (2004). Co-creation Experiences: The Next Practice in Value Cretion. Journal of Interactive Marketing, 18(3), pp. 5-18. https://doi.org/10.1002/ dir.20015

[15] Roser, T., DeFillippi, R. \& Samson, A. (2013). Managing Your Co-creation Mix: Co-creation ventures in Distinctive Contexts. European Business Review, 25(1), 1-35. https://doi. org/10.1108/09555341311287727

[16] Bughin, J. (2014, December). Three Ways Companies Can Make Co-creation Pay Off. Retrieved October 8, 2015, from McKinsey: http://www.mckinsey.com/insights/consumer_and_retail/three_ways_companies_can_make_co-creation_pay_off

[17] Koenaite, M., Chuchu, T., \& Venter de Villiers, M. (2019). The Impact of Mobile Banking on the Adoption of Banking Products and Services in South Africa, using the Technology Acceptance Model. Journal of Business \& Retail Management Research, 13(3), 93- 103. https://doi.org/10.24052/jbrmr/v13is03/art-09

[18] Zhou, T., Lu, Y., \& Wang, B. (2010). Integrating TTF and UTAUT to explain mobile banking user adoption. Computers in human behaviour, 26(4), 760-767. https://doi.org/10. 1016/j.chb.2010.01.013

[19] John, D. (2015, November 25). The 4000-year Transition to Digital Banking. Retrieved November 27, 2015, from The Market Mogul: http://themarketmogul.com/4000-year-transition-digital-banking/ 
[20] Singh, A. N. (2004). Trends in South African Internet Banking. New Information Perspectives, pp. 187-196.

[21] India infoline News. (2015, November 24). Digital Banking Summit: Technology shifts digitizing entire banking process. Retrieved November 27, 2015, from India Infoline: http://www.indiainfoline.com/article/news-top-story/digital-banking-summit-technologyshifts-digitizing-entire-banking-process-115112400564 1.html

[22] Toplin, J. (2015). Digital banking channels are serving millennials' needs. Retrieved November 27, 2015, from Business Insider: http://www.businessinsider.com/digital-bankingchannels-are-serving-millennials-needs-2015-10

[23] Adeyanju, O. D. (2014). Code of Ethics and professionalism: Implication for Bank Failure in Nigeria. Research Journal of Finance and Accounting, 5(19), 75-86.

[24] Chalcraft, D., Hilton, T. \& Hughes, T. (2015). Customer, Collaborator or Co-creator? What is the Role of the Student in a Changing Higher Education Servicescape? Journal of higher Marketing for Higher Education, 25(1), 1-4, doi: https://doi.org/10.1080/08841241. $\underline{2015.1044790}$

[25] Oldemaat, L. (2013). Co-Creation: The 'P' of Participation. Enschede, Netherlands: University of Twente.

[26] Deci, E. L. \& Ryan, R. M. (1985). Intrinsic Motivation and Self- determination in Human Behavior. New York: Plenum.

[27] Rogers, C. R. (1962). The interpersonal relationship. Harvard educational review, 32(4), 416-429.

[28] Ryan, R.M., Patrick, H., Deci, E.L. \& Williams, G.C. (2008). Facilitating Health Behavior Change and its Maintenance: Interventions Based on Self-determination Theory. The European Health Psychologist, 10(1), pp.2-5.

[29] Teixeira, P. J., Carraça, E. V., Markland, D., Silva, M. N., \& Ryan, R. M. (2012). Exercise, physical activity, and self-determination theory: a systematic review. International journal of behavioral nutrition and physical activity, 9(1), 78. 1-30 https://doi.org/10.1186/1479$\underline{5868-9-78}$

[30] Hosseini, M. R., Chileshe, N., Zuo, J. \& Baroudi, B. (2015). Adopting Global Virtual Engineering Teams in AEC Projects. Construction Innovation, 151-179. Volume and issue number? https://doi.org/10.1108/ci-12-2013-0058

[31] Sahin, I. (2006). Detailed Review of Rogers' Diffusion of Innovations Theory and Educational Technology-Related Studies Based on Rogers' Theory. Turkish Online Journal of Educational Technology, 5, pp. 14-23.

[32] Aslani, A. and Naaranoja, M. (2015). A Systematic-Qualitative Research for Diffusion of Innovation in the Primary Healthcare Centers. Journal of Modelling in Management, pp. 105-117. https://doi.org/10.1108/jm2-04-2013-0016

[33] Murray, C. E. (2009). Diffusion of Innovation Theory: A Bridge for the Research-Practice Gap in Counseling. Journal of Counseling and Development, pp. 108-116. https://doi.org/ 10.1002/j.1556-6678.2009.tb00556.x

[34] Rogers, E.M., 2010. Diffusion of innovations. New York: Simon and Schuster.

[35] Gnoth, J. (1994). Tourism motivation and expectation formation. Annals of Tourism Research, 24(2), 283-304. https://doi.org/10.1016/s0160-7383(97)80002-3

[36] Budiman, S. (2012). Analysis of Consumer Attitudes to Purchase Intentions of Counterfeiting Bag Products in Indonesia. International Journal of Management, Economics and Social Sciences, 1(1), 1-12.

[37] Kohler, T., Fuller, J., Matzler, K. \& Stieger, D. (2011). Co-creation in Virtual Worlds: The Design of the User Experience. MIS Quarterly, 35(3), 773-788. https://doi.org/10.2307/23 $\underline{042808}$ 
[38] Gomes, M. J., Nogueira, A. J., Antão, C., \& Teixeira, C. (2019). Motivations and attitudes towards the act of blood donation among undergraduate health science students. Transfusion and Apheresis Science, 58(2), 147-151. https://doi.org/10.1016/j.transci.2018.12.018

[39] Plante, C. N., Rosenfeld, D. L., Plante, M., \& Reysen, S. (2019). The role of social identity motivation in dietary attitudes and behaviors among vegetarians. Appetite. 141. 1-9 https:// doi.org/10.1016/j.appet.2019.05.038

[40] Ajzen, I. \& Fishbein, M. (2005). The Influence of Attitudes on Behavior. In D. Albarracin, B. T. Johnson, \& M. P. Zanna, The Handbook of Attitudes (pp. 173-221). Mahwah: Erlbaum

[41] De Matos, C. A., Ituassu, C. T. \& Rossi, C. A. (2007). Consumer Attitudes Toward Counterfeits: A Review and Extension. Journal of Consumer Marketing, 24, pp. 36-47. https:// doi.org/10.1108/07363760710720975

[42] Ndubisi, N. O. \& Sinti, Q. (2006). Consumer Attitudes, System's Characteristics and Internet Banking Adoption in Malaysia. Management Research News, 29, pp. 16-27. https:// doi.org/10.1108/01409170610645411

[43] Lee, J. E., \& Shin, E. (2019). The effects of apparel names and visual complexity of apparel design on consumers' apparel product attitudes: A mental imagery perspective. Journal of Business Research. (In press) https://doi.org/10.1016/j.jbusres.2019.08.023

[44] Leong, L.Y., Ooi, K.B., Chong, A.Y.L. \& Lin, B. (2013). Modeling the Stimulators of the Behavioral Intention to Use Mobile Entertainment: Does Gender Really Matter? Computers in Human Behavior, 29(5), 2109-2121. https://doi.org/10.1016/j.chb.2013.04.004

[45] Cheung, W., Chang, M. K. \& Lai, V. S. (2000). Prediction of Internet and World Wide Web Usage at Work. Decision Support Systems, 30, 83-100. https://doi.org/10.1016/s0167 $-9236(00) 00125-1$

[46] Lin, H. (2011). An Empirical Investigation of Mobile Banking Adoption: The Effect of Innovation Attributes and Knowledge-based Trust. International Journal of Information Management, 3(3), 252-260. https://doi.org/10.1016/j.ijinfomgt.2010.07.006

[47] Au, Y.A. \& Kauffman, R.J. (2008). The Economics of Mobile Payments: Understanding Stakeholder Issues for an Emerging Financial Technology Application. Electronic Commerce Research and Applications, 7(2), 141-164. https://doi.org/10.1016/j.elerap.2006. $\underline{12.004}$

[48] Chen, L., M. Gillenson, \& D. Sherrell (2004). Consumer acceptance of virtual stores: A Theoretical Model and Critical Success Factors for Virtual Stores. ACM SIGMIS Database, 35(2), pp. 8-31. https://doi.org/10.1145/1007965.1007968

[49] Kanchanatanee, K., Suwanno, N., \& Jarernvongrayab, A. (2014). Effects of attitude toward using, perceived usefulness, perceived ease of use and perceived compatibility on intention to use E-marketing. Journal of Management Research, 6(3), 1-13. https://doi.org/10.5296/ jmr.v6i3.5573

[50] To, M. L., \& Ngai, E. W. (2007). The role of managerial attitudes in the adoption of technological innovations: an application to B2C e-commerce. International Journal of Enterprise Information Systems 3(2), 23-33 https://doi.org/10.4018/jeis.2007040102

[51] Keesee, G. S. \& Shepard, M. (2011). Perceived Attributes Predict Course Management System Adopter Status. Online Journal of Distance Learning Administration, 4, pp. 1-4.

[52] Lee, Y., Hsieh, Y., \& Hsu, C. (2011). Adding Innovation Diffusion Theory to the Technology Acceptance Model: Supporting Employees' Intentions to Use e-Learning Systems. Educational Technology \& Society, 14, pp. 124-137.

[53] Reynolds, N. \& Ruiz de Maya, S. (2013). The Impact of Complexity and Perceived Difficulty on Consumer Revisit Intentions. Journal of Marketing Management, 29(5-6), 625-645. https://doi.org/10.1080/0267257x.2013.774290 
[54] Chuchu, T., \& Ndoro, T. (2019). An examination of the determinants of the adoption of mobile applications as learning tools for higher education students. International Journal of Interactive Mobile Technologies, 13(3), 53-67 https://doi.org/10.3991/ijim.v13i03.10195

[55] Wu, J. H., \& Wang, S. C. (2005). What drives mobile commerce? An empirical evaluation of the revised technology acceptance model. Information \& Management, 42(5), 719-729. https://doi.org/10.1016/j.im.2004.07.001

[56] Duan, Y., He, Q., Feng, W., Li, D. \& Fu, Z. (2010). A Study on E-learning Take-up Intention from an Innovation Adoption Perspective: A case in China. Computers \& Education, 55(1), pp. 237-246. https://doi.org/10.1016/j.compedu.2010.01.009

[57] Gorsuch, R. L. (1983). Factor Analysis (2nd ed.). Hillsdale, NJ: Erlbaum.

[58] Comrey, A. L. \& Lee, H. B. (1992). A First Course in Factor Analysis (2nd ed.). Hillsdale, NJ: Erlbaum.

[59] Boomsma, A. \& Hoogland, J.J. (2001). The Robustness of LISREL Modeling Revisited: Structural Equation Models: Present and Future. A Festschrift in honor of Karl Jöreskog, 2(3), pp.139-168.

[60] Zhao, Y. C., \& Zhu, Q. (2014). Effects of Extrinsic and Intrinsic Motivation on Participation in Crowdsourcing Contests. Online Information Review, 38, pp. 896-917. https://doi. org/10.1108/oir-08-2014-0188

[61] Zheng, H., Li, D. \& Hou, W. (2011). Task design, motivation, and participation in crowdsourcing contests. International Journal of Electronic Commerce, 15(4), pp. 57-88. https://doi.org/10.2753/jec1086-4415150402

[62] Ahluwalia, R., Unnava, H.R. \& Burnkrant, R.E. (2001). The Moderating Role of Commitment on the Spillover Effect of Marketing Communications. Journal of Marketing Research, 38(4), 458-470. https://doi.org/10.1509/jmkr.38.4.458.18903

[63] Ewe, S. Y., Yap, S. F. \& Lee, C. K. (2015). Network Externalities and the Perception of Innovation Characteristics: Mobile Banking. Marketing Intelligence \& Planning, 33, 592611. https://doi.org/10.1108/mip-01-2014-0006

[64] López-Nicolás, C., Molina-Castillo, F. J., \& Bouwman, H. (2008). An assessment of advanced mobile services acceptance: Contributions from TAM and diffusion theory models. Information \& Management, 45(6), 359-364. https://doi.org/10.1016/j.im.2008.05.001

[65] Barber, N., Kuo, P.J., Bishop, M. \& Goodman Jr, R. (2012). Measuring Psychographics to Assess Purchase Intention and Willingness to Pay. Journal of consumer marketing, 29(4), pp.280-292. https://doi.org/10.1108/07363761211237353

[66] Hooper, D., Coughlan, J. \& Mullen, M. R. (2008). Structural Equation Modelling: Guidelines for Determining Model Fit. Electronic Journal of Business Research Methods, 6, pp. 53-60.

[67] Tabachnick, B.G., Fidell, L.S. and Ullman, J.B. (2007). Using multivariate statistics (Vol. 5). Boston, MA: Pearson.

[68] Krishnamurthy, S. (2006). On the Intrinsic and Extrinsic Motivation of Free/Libre/Open Source (FLOSS) Developers. Knowledge, Technology \& Policy, 18(4), 17-39. https://doi. org/10.1007/s12130-006-1002-x

[69] Watchravesringkan, K., Hodges, N. N., \& Kim, Y. H. (2010). Exploring consumers' adoption of highly technological fashion products. Journal of Fashion Marketing and Management: An International Journal, 14(2), 263-281. https://doi.org/10.1108/13612021011046 $\underline{101}$

[70] Ponsignon, F., Klaus, P. \& Maull, R. S. (2015). Experience Co-creation in Financial Services: An Empirical Exploration. Journal of Service Management, 26(2), 295-320. https:/ /doi.org/10.1108/josm-10-2014-0277 
[71] Ind., N. \& Coates, N. (2013). The Meaning of Co-creation. European Business Review, 25(1), 86-95.

[72] Hoehle, H. \& Venkatesh, V. (2015). Mobile Application Usability: Conceptualization and Instrument Development. Mis Quarterly, 39(2), 435-472. https://doi.org/10.25300/misq/ 2015/39.2.08

[73] Maziriri, E. T., Mapuranga, M., \& Madinga, N. W. (2019). Navigating selected perceived risk elements on investor trust and intention to invest in online trading platforms. Journal of Economic and Financial Sciences, 12(1), 1-14. https://doi.org/10.4102/jef.v12i1.434

\section{Authors}

Dr Marike Venter de Villiers Ph.D. is the Head of the Marketing division in the School of Business Sciences at the University of the Witwatersrand. Dr Venter de Villiers has a research focus in Consumer Behaviour.

Dr Tinashe Chuchu Ph.D. is a senior lecturer in the Department of Marketing Management of the faculty of Economic and Management Sciences at the University of Pretoria. Dr Chuchu's research area of focus is in Customer Decision-making, Consumer Behaviour and Marketing Management. Dr Chuchu has published numerous articles in international journals.

Ms Gugu Valerie Chavarika is a student in the Marketing division of the School of Business Sciences at the University of the Witwatersrand. Ms Gugu Chavarika has a research focus in Consumer Behaviour.

Article submitted 2020-02-14. Resubmitted 2020-03-21. Final acceptance 2020-03-29. Final version published as submitted by the authors. 